\title{
Betaine, organic acids and inulin do not affect ileal and total tract nutrient digestibility or microbial fermentation in piglets*
}

\author{
A. Ratriyanto ${ }^{1,2}$, R. Mosenthin ${ }^{1,3}$, D. Jezierny ${ }^{1}$, N. Sauer ${ }^{1}$ \\ and M. Eklund ${ }^{1}$ \\ ${ }^{1}$ Institute of Animal Nutrition, University of Hohenheim \\ Emil-Wolff-Str. 10, 70593, Stuttgart, Germany \\ ${ }^{2}$ Department of Animal Science, Sebelas Maret University \\ Jl. Ir. Sutami 36A, 57126, Surakarta, Indonesia
}

(Received 16 January 2009; revised version 22 April 2009; accepted 24 June 2009)

\begin{abstract}
The study was conducted to investigate the effects of betaine alone or combined with organic acids and inulin on ileal and total tract nutrient digestibilities and intestinal microbial fermentation characteristics in piglets. In total, 24 four-week-old barrows with an average initial body weight of $6.7 \mathrm{~kg}$ were used in two consecutive experiments with 12 piglets each. Betaine, organic acids and inulin at a level of $0.2,0.4$ and $0.2 \%$, respectively, or combinations of these supplements were added to the basal diet. The supplementation of betaine, organic acids and inulin or any of their combinations did not affect ileal and total tract nutrient digestibilities. The microbial fermentation products both at the ileal and faecal level were not affected by any of the treatments. In conclusion, combining betaine with organic acids and inulin did not have any associated effects on the variables that were measured.
\end{abstract}

KEY WORDS: piglet, betaine, organic acids, inulin, digestibility, microbial fermentation

\section{INTRODUCTION}

Dietary supplementation with betaine, the trimethyl derivative of the amino acid glycine, has recently been shown to increase microbial fermentation of

\footnotetext{
* Supported by AHRHOFF GmbH, Bönen, Germany

${ }^{3}$ Corresponding author: e-mail: rhmosent@uni-hohenheim.de
} 
dietary fibre and protein in piglets (Eklund et al., 2006a,b; Ratriyanto et al., 2007). Improved digestion of dietary fibre has been associated with increased energy availability to the pig (e.g., Fang et al., 2007). In contrast, microbial fermentation of amino acids results in the production of several putrefactive compounds such as ammonia and cadaverine, which are toxic to the pig at high concentrations (Mosenthin et al., 1992).

Organic acids have been shown to support digesta acidification in the stomach, thereby increasing proteolytic enzyme activity, which subsequently may improve the digestibility of crude protein and amino acids in pigs (Gabert and Sauer, 1994). In consequence, associated with enhanced amino acid digestibility, microbial fermentation of undigested dietary protein is reduced (Mosenthin et al., 1992; Blank et al., 1999).

Furthermore, by providing sufficient fermentable carbohydrates as an energy source for the intestinal microbiota, fermentation of protein may be prevented (Houdijk, 1998). Certain dietary non-digestible oligosaccharides (NDO), such as inulin and fructo-oligosaccharides (FOS), are considered to be prebiotics because they are indigestible by intestinal host enzymes, and thus may serve as fermentable substrates for intestinal microflora (Houdijk et al., 2002). There is increasing evidence, however, that, at least in pigs, some prebiotic carbohydrates, e.g., FOS, are already completely fermented by the end of the terminal ileum, and are therefore unavailable for the microbiota distal to the ileum (Houdijk, 1998). Thus, it was suggested that the use of rather slowly fermentable NDO in the diet of pigs might have an advantage over rapidly fermentable substrates (Steer et al., 2000).

Thus, it is hypothesized that the combined supplementation of betaine with organic acids and/or inulin in piglet diets may improve digestive functions due to different modes of actions. These include enhanced microbial fibre fermentation due to betaine supplementation. Moreover, supplemental organic acids may aid in optimizing proteolytic conditions proximal to the large intestine, thereby improving the digestibility of feed proteins. Finally, supplemental inulin may be used as a fermentable substrate by the microbiota harboured in the distal regions of the gastrointestinal tract, contributing to higher production of short-chain fatty acids (SCFA). Therefore, the objective of the study was to determine the effects of betaine alone or in combination with organic acids and/or inulin on ileal and total tract nutrient digestibilities and intestinal microbial fermentation characteristics in piglets.

\section{MATERIAL AND METHODS}

\section{Animals and housing}

A total of 2 consecutive experiments, each with 12 four-week-old barrows 
(German Landrace $\times$ Piétrain) from the University of Hohenheim Research Station, was conducted. The average initial and final body weight (BW) of the pigs was $6.7 \pm 1.2$ and $11.2 \pm 2.3 \mathrm{~kg}$, respectively. The piglets were individually housed in stainless-steel metabolic crates $(0.75 \mathrm{~m} \times 1 \mathrm{~m})$. The temperature in the research unit, which was equipped with an automatic temperature control system, was set at $20^{\circ} \mathrm{C}$. Each crate was equipped with an infrared heating lamp and a low pressure drinking nipple.

\section{Surgical procedure}

The piglets were surgically fitted with simple T-cannulas at the distal ileum on day 5 and day 6 after arrival, according to the principles described by Li et al. (1993). The cannulas were prepared from a plastisol solution (Techniplast, FH and Sons, Toronto, Canada) according to the procedures as outlined by Li et al. (1993). The experimental protocol was approved by the German Ethical Commission for Animal Welfare. Care of the animals used in this experiment was in accordance with the guidelines issued by the German regulation for care and treatment of animals (Lorz and Metzger, 1999).

\section{Diets and feeding}

The basal diet consisted of wheat, barley, soyabean meal, maize starch, a mineral and vitamin premix and titanium dioxide as a digestibility marker (Table 1). The diet was prepared according to NRC (1998) requirement for piglets from 5 to $10 \mathrm{~kg} \mathrm{BW}$. The basal diet was fed alone or supplemented with $0.2 \%$ betaine, $0.4 \%$ organic acids (blend of $35 \%$ formic acid, $35 \%$ lactic acid, $20 \%$ citric acid and

Table 1 . The basal diet, $\%$ as fed

\begin{tabular}{lc}
\hline Ingredient & Content \\
\hline Barley & 37.6 \\
Wheat & 31.1 \\
Soyabean meal & 18.0 \\
Maize starch & 6.8 \\
Soyabean oil & 2.0 \\
Mineral and vitamin premix ${ }^{1}$ & 4.0 \\
Titanium dioxide & 0.5
\end{tabular}

${ }^{1}$ the mineral and vitamin premix supplied the following per kg diet; IU: vit. A 14400, vit. $\mathrm{D}_{3} 1600$; mg: vit. C 120, vit. E 160 , vit. $\mathrm{K}_{3} 2.4$, vit. $\mathrm{B}_{1} 2.56$, vit. $\mathrm{B}_{2} 5.76$, vit. $\mathrm{B}_{6} 3.2$, pantothenic acid 24, biotin 240, choline chloride 250, Cu 140, Zn 100, Mn 75, Fe 120, Se 0.45, Co 1.8, I 3; g: Ca 6.2, P 2.4, $\mathrm{Na} 1.4, \mathrm{Mg} 1.2$, L-lysine $\mathrm{HCl} 4$, DL-methionine 1.2, L-threonine 1.8, L-tryptophan 0.32; $\mu \mathrm{g}$ : vit. $\mathrm{B}_{12}$ 38.4, folic acid 1.44, nicotinic acid 32 
$10 \%$ sorbic acid), or $0.2 \%$ inulin, or with any combination of these supplements. The basal diet was defined as the control treatment. The remaining 7 assay diets were referred to as betaine (BET), organic acids (AC), inulin (IN), betaine + organic acids $(\mathrm{BET}+\mathrm{AC})$, betaine + inulin $(\mathrm{BET}+\mathrm{IN})$, organic acids + inulin $(\mathrm{AC}+\mathrm{IN})$, betaine + organic acids + inulin $(\mathrm{BET}+\mathrm{AC}+\mathrm{IN})$ treatments. The diets were fed in a mash form, mixed with water $(1 / 1 \mathrm{w} / \mathrm{v})$, twice daily at 07.00 and $19.00 \mathrm{~h}$ at a total level of $4.5 \%$ of individual BW. The BW of the pigs was determined at the beginning of each of the 2 experimental periods. The pigs had free access to water.

\section{Experimental procedure}

After a 2- to 3-day recuperation period from surgery, the pigs were fed their assay diets. Each of the 2 experiments consisted of 2 experimental periods, each comprising 7 days for adaptation to the assay diets, 3 days for faeces collection, and 2 days for digesta sampling. The collection of faeces started at $07.00 \mathrm{~h}$ on day 8 and continued for 72 consecutive hours using adhesive collection bags attached to the pigs' anus. Faeces were collected twice daily. Ileal digesta was collected for $2 \times 12 \mathrm{~h}$, from 07.00 to $19.00 \mathrm{~h}$ on day 11 and from 19.00 to $07.00 \mathrm{~h}$ on day 12. The collection procedure for ileal digesta was adapted from Li et al. (1993) using plastic tubing attached to the barrel of the cannula by elastic bands. The plastic tubing was changed at least every $20 \mathrm{~min}$. During digesta collection, $2 \mathrm{ml}$ of $2.5 \mathrm{M}$ formic acid was added to the plastic tubing to minimize further bacterial fermentation in digesta, with exception for the samples for the determination of lactic acid and SCFA concentrations. Digesta and faeces samples were immediately frozen at $-30^{\circ} \mathrm{C}$. Ileal and faecal samples were pooled and mixed within animal and period, and were freeze-dried thereafter. Samples of diets, ileal digesta and faeces were milled through a $0.5 \mathrm{~mm}$ mesh screen prior to analyses.

\section{Analytical procedure}

Determination of dry matter (DM), crude ash (CA), crude protein (CP), ether extracts (EE), neutral detergent fibre (NDF), acid detergent fibre (ADF) and amino acids (AA) was performed according to Naumann and Bassler (1997). Amino acid analyses including diaminopimelic acid (DAP) and ornithine analyses were performed by means of ion exchange chromatography (Amino Acid Analyzer LC 300, Eppendorf Biotronic) using post column derivatization with ninhydrin. The D- and L-lactic acid concentrations were determined by means of a photometric test kit (Boehringer, No. 1112 821). The SCFA concentrations were measured by gas chromatography using 4-methyl-isovalerianic acid as internal standard. 
Samples for SCFA analyses were prepared according to the principles described by Zijlstra et al. (1977). The titanium dioxide contents in feed, ileal digesta and faecal samples were determined according to the procedures described by Brandt and Allam (1987).

\section{Statistical analyses}

The study was conducted as a $2 \times 2 \times 2$ factorial experimental design with 2 supplemental levels of betaine $(0,0.2 \%), 2$ levels of organic acids $(0,0.4 \%)$ and 2 levels of inulin $(0,0.2 \%)$, and was balanced over 2 experiments, each including 2 experimental periods. Within each of the 2 experiments, the animals were randomly allocated to 1 of the 8 dietary treatments in each of the 2 periods, resulting in a total of 6 observations per treatment. The data were subjected to mixed model analysis using the MIXED procedure of SAS (2003). The linear model included betaine, organic acids, inulin, experiment, period, and their interactions as fixed effects, whereas animal within experiment was considered a random effect. The significance level was set at $\mathrm{P}=0.05$. Significant differences between treatments were indicated by different superscript letters using the algorithm for letter-based representation of all pair-wise comparisons according to Piepho (2004).

\section{RESULTS AND DISCUSSION}

All animals seemed healthy throughout the experiment and readily consumed their feed allowances. The analysed chemical composition of the basal diets is presented in Table 2.

Table 2. Nutrient composition of the basal diet, \% dry matter

\begin{tabular}{|c|c|c|c|c|c|}
\hline \multicolumn{2}{|l|}{ Nutrients } & \multicolumn{2}{|c|}{ Indispensable AA } & \multicolumn{2}{|c|}{ Dispensable AA } \\
\hline Dry matter & 89.0 & Arginine & 1.01 & Alanine & 0.67 \\
\hline Crude protein & 17.4 & Histidine & 0.40 & Aspartic acid & 1.52 \\
\hline Ether extracts & 4.3 & Isoleucine & 0.63 & Cystine & 0.30 \\
\hline Crude ash & 6.1 & Leucine & 1.23 & Glutamic acid & 3.65 \\
\hline $\mathrm{NDF}$ & 10.6 & Lysine & 1.29 & Glycine & 0.69 \\
\hline $\mathrm{ADF}$ & 4.3 & Methionine & 0.34 & Proline & 1.14 \\
\hline $\mathrm{Ca}^{1}$ & 0.8 & Phenylalanine & 0.82 & Serine & 0.85 \\
\hline \multirow[t]{2}{*}{$\mathrm{P}^{1}$} & 0.6 & Threonine & 0.82 & Tyrosine & 0.47 \\
\hline & & Valine & 0.76 & & \\
\hline
\end{tabular}

${ }^{1}$ calculated values 
The supplementation of betaine alone or combined with organic acids and/or inulin did not affect the ileal digestibilities of DM, CP, EE, CA, NDF, ADF or AA $(\mathrm{P}>0.05$; Tables 3 and 4$)$. For all treatments, the ileal digestibility values averaged $72,78,80,43,18$ and $-2 \%$, for DM, CP, EE, CA, NDF and ADF, respectively. The average ileal AA digestibilities ranged from $68 \%$ for glycine, up to $87 \%$ for glutamic acid. Similar digestibility coefficients have been reported for piglets fed a diet based on wheat, barley and soyabean meal (Eklund et al., 2006b; Ratriyanto et al., 2007).

Table 3. Ileal dry matter and nutrient digestibilities in pigs fed on diets supplemented with betaine, organic acids, inulin and their combinations, $\%$

\begin{tabular}{|c|c|c|c|c|c|c|c|c|c|}
\hline \multirow[b]{2}{*}{ Item } & \multicolumn{8}{|c|}{ Treatments } & \multirow[b]{2}{*}{$\begin{array}{c}\text { Pooled } \\
\text { SEM }\end{array}$} \\
\hline & $\mathrm{CON}$ & BET & $\mathrm{AC}$ & IN & $\begin{array}{l}\text { BET } \\
+\mathrm{AC}\end{array}$ & $\begin{array}{l}\text { BET } \\
+ \text { IN }\end{array}$ & $\begin{array}{l}\mathrm{AC} \\
+\mathrm{IN}\end{array}$ & $\begin{array}{c}\text { BET+ } \\
\mathrm{AC}+\mathrm{IN}\end{array}$ & \\
\hline Dry matter & 73.0 & 71.2 & 72.5 & 72.1 & 70.8 & 72.0 & 70.6 & 71.1 & 0.95 \\
\hline Crude ash & 43.9 & 41.6 & 44.0 & 43.8 & 41.5 & 41.7 & 42.2 & 41.3 & 1.95 \\
\hline Ether extracts & 79.9 & 79.2 & 80.8 & 80.6 & 80.6 & 80.5 & 80.3 & 80.4 & 1.05 \\
\hline Crude protein & 78.5 & 77.0 & 79.3 & 78.4 & 76.9 & 77.7 & 77.2 & 78.2 & 1.17 \\
\hline NDF & 20.3 & 18.9 & 20.4 & 21.8 & 19.6 & 16.9 & 14.5 & 13.6 & 3.69 \\
\hline $\mathrm{ADF}$ & 2.6 & 2.0 & 1.0 & 6.8 & -2.2 & -3.2 & -5.5 & -4.4 & 5.23 \\
\hline
\end{tabular}

CON - control treatment; BET - betaine treatment; AC - organic acids treatment; IN - inulin treatment; $\mathrm{BET}+\mathrm{AC}$ - betaine + organic acids treatment; $\mathrm{BET}+\mathrm{IN}$ - betaine + inulin treatment; $\mathrm{AC}+\mathrm{IN}$ - organic acids + inulin treatment; $\mathrm{BET}+\mathrm{AC}+\mathrm{IN}$ - betaine + organic acids + inulin treatment

Table 4. Ileal amino acid digestibilities in pigs fed on diets supplemented with betaine, organic acids, inulin and their combinations, $\%$

\begin{tabular}{|c|c|c|c|c|c|c|c|c|c|}
\hline \multirow[b]{2}{*}{ Item } & \multicolumn{8}{|c|}{ Treatments $^{1}$} & \multirow[b]{2}{*}{$\begin{array}{c}\text { Pooled } \\
\text { SEM }\end{array}$} \\
\hline & $\mathrm{CON}$ & BET & $\mathrm{AC}$ & IN & $\begin{array}{l}\text { BET } \\
+\mathrm{AC} \\
\end{array}$ & $\begin{array}{l}\text { BET } \\
+\mathrm{IN} \\
\end{array}$ & $\begin{array}{l}\mathrm{AC} \\
+\mathrm{IN} \\
\end{array}$ & $\begin{array}{c}\text { BET+ } \\
\mathrm{AC}+\mathrm{IN}\end{array}$ & \\
\hline \multicolumn{10}{|l|}{ Indispensable $A A$} \\
\hline arginine & 85.0 & 83.7 & 85.8 & 84.4 & 83.9 & 84.5 & 83.5 & 84.3 & 0.94 \\
\hline histidine & 80.5 & 79.3 & 82.3 & 80.9 & 79.3 & 80.0 & 79.6 & 80.1 & 1.35 \\
\hline isoleucine & 81.5 & 78.9 & 81.9 & 80.5 & 80.0 & 80.6 & 79.0 & 80.7 & 0.98 \\
\hline leucine & 80.1 & 78.3 & 81.2 & 79.7 & 78.7 & 79.0 & 78.4 & 79.3 & 1.38 \\
\hline lysine & 86.3 & 85.2 & 86.9 & 86.4 & 85.5 & 85.7 & 85.4 & 86.1 & 0.85 \\
\hline phenylalanine & 81.2 & 79.4 & 82.2 & 80.7 & 80.9 & 80.3 & 79.6 & 80.3 & 1.24 \\
\hline threonine & 78.9 & 76.7 & 79.4 & 78.7 & 76.9 & 77.9 & 76.5 & 78.1 & 1.21 \\
\hline valine & 78.8 & 76.8 & 80.1 & 78.5 & 77.6 & 78.1 & 77.1 & 78.4 & 1.23 \\
\hline \multicolumn{10}{|l|}{ Dispensable AA } \\
\hline alanine & 73.9 & 71.6 & 75.0 & 73.7 & 72.2 & 72.3 & 71.8 & 73.4 & 1.79 \\
\hline aspartic acid & 77.8 & 75.7 & 78.4 & 77.6 & 76.0 & 77.1 & 76.4 & 77.6 & 1.13 \\
\hline glutamic acid & 87.3 & 86.1 & 87.7 & 87.4 & 86.3 & 87.1 & 86.4 & 87.0 & 0.84 \\
\hline glycine & 68.4 & 66.6 & 70.5 & 68.6 & 65.3 & 68.6 & 68.4 & 69.8 & 1.86 \\
\hline proline & 82.4 & 81.1 & 82.4 & 82.6 & 79.1 & 81.7 & 80.0 & 81.8 & 1.42 \\
\hline serine & 78.3 & 76.4 & 78.9 & 78.3 & 76.6 & 77.5 & 76.7 & 77.9 & 1.34 \\
\hline tyrosine & 81.1 & 79.0 & 81.5 & 80.4 & 79.3 & 80.0 & 78.9 & 80.1 & 1.19 \\
\hline
\end{tabular}


Among individual AA, digestibility values for arginine and glutamic acid were relatively high, whereas those of threonine and glycine were relatively low which is in agreement with previous studies in piglets (Li et al., 1993). Similar to ileal digestibility values there were no effects of betaine, supplemented alone or provided in combination with organic acids and/or inulin, on total tract digestibilities of DM, CP, EE, CA, NDF, ADF and AA (P>0.05; Tables 5 and 6).

Recent studies in piglets revealed variable responses of dietary betaine supplementation on DM digestibility (Eklund et al., 2006a,b; Ratriyanto et al.,

Table 5. Total tract dry matter and nutrient digestibilities in pigs fed on diets supplemented with betaine, organic acids, inulin and their combinations

\begin{tabular}{|c|c|c|c|c|c|c|c|c|c|}
\hline \multirow[b]{2}{*}{ Item } & \multicolumn{8}{|c|}{ Treatments $^{1}$} & \multirow[b]{2}{*}{$\begin{array}{c}\text { Pooled } \\
\text { SEM }\end{array}$} \\
\hline & $\mathrm{CON}$ & BET & $\mathrm{AC}$ & IN & $\begin{array}{l}\text { BET } \\
+\mathrm{AC} \\
\end{array}$ & $\begin{array}{l}\text { BET } \\
+\mathrm{IN} \\
\end{array}$ & $\begin{array}{l}\mathrm{AC} \\
+\mathrm{IN} \\
\end{array}$ & $\begin{array}{c}\text { BET+ } \\
\mathrm{AC}+\mathrm{IN}\end{array}$ & \\
\hline Dry matter & 86.5 & 86.1 & 86.2 & 85.9 & 85.8 & 86.1 & 85.5 & 86.1 & 0.44 \\
\hline Crude ash & 57.2 & 59.0 & 55.5 & 57.9 & 58.0 & 56.9 & 58.0 & 56.6 & 1.83 \\
\hline Ether extracts & 69.3 & 70.2 & 65.1 & 68.9 & 68.1 & 69.7 & 67.2 & 69.9 & 2.36 \\
\hline Crude protein & 85.8 & 84.2 & 83.3 & 83.3 & 83.0 & 83.5 & 82.4 & 85.7 & 1.19 \\
\hline NDF & 52.1 & 50.6 & 55.6 & 51.1 & 50.4 & 53.4 & 51.3 & 49.5 & 1.86 \\
\hline $\mathrm{ADF}$ & 24.7 & 22.2 & 30.5 & 21.9 & 22.2 & 26.8 & 22.9 & 21.7 & 2.80 \\
\hline
\end{tabular}

${ }^{1}$ explanation see Table 3

Table 6. Total tract amino acid digestibilities in pigs fed on diets supplemented with betaine, organic acids, inulin and their combinations

\begin{tabular}{|c|c|c|c|c|c|c|c|c|c|}
\hline \multirow[b]{2}{*}{ Item } & \multicolumn{8}{|c|}{ Treatments $^{1}$} & \multirow[b]{2}{*}{$\begin{array}{c}\text { Pooled } \\
\text { SEM }\end{array}$} \\
\hline & $\mathrm{CON}$ & BET & $\mathrm{AC}$ & IN & $\begin{array}{l}\text { BET } \\
+ \text { AC }\end{array}$ & $\begin{array}{l}\text { BET } \\
+ \text { IN }\end{array}$ & $\begin{array}{l}\mathrm{AC} \\
+\mathrm{IN}\end{array}$ & $\begin{array}{c}\text { BET+ } \\
\text { AC+IN }\end{array}$ & \\
\hline \multicolumn{10}{|l|}{ Indispensable AA } \\
\hline arginine & 90.7 & 89.1 & 88.7 & 88.3 & 87.9 & 88.9 & 87.9 & 90.7 & 0.85 \\
\hline histidine & 88.8 & 87.8 & 87.6 & 86.7 & 86.4 & 87.0 & 86.4 & 89.9 & 0.75 \\
\hline isoleucine & 84.8 & 82.7 & 81.4 & 81.7 & 79.8 & 81.3 & 79.6 & 83.5 & 1.26 \\
\hline leucine & 85.3 & 83.9 & 83.0 & 82.9 & 81.9 & 83.1 & 81.9 & 85.4 & 1.10 \\
\hline lysine & 89.1 & 89.3 & 87.0 & 86.4 & 85.8 & 87.0 & 85.5 & 88.7 & 0.96 \\
\hline phenylalanine & 86.2 & 85.1 & 83.8 & 84.0 & 83.2 & 84.0 & 82.9 & 86.4 & 1.05 \\
\hline threonine & 85.8 & 84.0 & 83.5 & 83.2 & 82.4 & 83.8 & 82.1 & 85.7 & 1.06 \\
\hline valine & 84.9 & 82.9 & 82.0 & 81.8 & 80.1 & 82.0 & 80.2 & 84.0 & 1.11 \\
\hline \multicolumn{10}{|l|}{ Dispensable AA } \\
\hline alanine & 78.9 & 75.9 & 74.9 & 74.0 & 72.9 & 75.0 & 72.3 & 78.0 & 1.74 \\
\hline aspartic acid & 85.6 & 83.2 & 83.1 & 82.3 & 81.6 & 83.1 & 81.3 & 85.1 & 1.14 \\
\hline glutamic acid & 92.8 & 91.7 & 91.5 & 91.0 & 90.8 & 91.4 & 90.5 & 92.7 & 0.59 \\
\hline glycine & 82.6 & 80.7 & 80.1 & 79.7 & 78.5 & 80.3 & 78.5 & 82.3 & 1.15 \\
\hline proline & 91.5 & 90.2 & 90.3 & 90.0 & 89.5 & 90.4 & 89.2 & 91.0 & 0.47 \\
\hline serine & 86.9 & 85.3 & 85.2 & 85.0 & 84.2 & 85.5 & 84.4 & 87.0 & 0.94 \\
\hline tyrosine & 82.9 & 81.3 & 79.5 & 80.3 & 78.7 & 80.4 & 78.6 & 83.1 & 1.56 \\
\hline
\end{tabular}

${ }^{1}$ explanation see Table 3 
2007). This variation may be due, at least in part, to the source of betaine used in these studies. For example, according to Eklund et al. (2006b), dietary supplementation with betaine-rich condensed molasses solubles increased ileal rather than total tract DM digestibility, whereas addition of betaine monohydrate to the diet did not improve ileal but total tract DM digestibility. In the present study, however, there was no effect of dietary supplementation of a liquid betaine product on either ileal or total tract DM digestibility ( $\mathrm{P}>0.05$ ). Furthermore, in contrast to the results of the present study, significantly higher, or at least a tendency towards higher, ileal and/or total tract digestibilities of EE, CA, AA, NDF and ADF were reported in piglets following dietary supplementation with betaine (Eklund et al., 2006a,b; Ratriyanto et al., 2007). There is speculation if these effects can be attributed to improvements in enzymatic digestion of nutrients, a higher absorption capacity of the intestinal epithelium and/or to enhanced fermentation activity of intestinal microflora (Eklund et al., 2006b; Ratriyanto et al., 2007). In fact, intestinal cells as well as microbes harbouring the digestive tract of pigs, may have a requirement for compatible osmolytes such as betaine (Eklund et al., 2005), as they have to cope with varying osmotic conditions along the digestive tract (Mongin, 1976). In poultry, for example, dietary betaine supplementation has shown to improve growth performance under stress conditions such as disturbed cell osmolarity (Klasing et al., 2002) or heat stress (Farooqi et al., 2005). There are claims that dietary betaine supplementation may compensate for stress situations such as sub-optimal hygienic and environmental standards (e.g., ambient temperature) in pig production systems (Spreeuwenberg et al., 2007). For example, Eklund et al. (2006a,b) obtained higher nutrient digestibilities in piglets kept at $25^{\circ} \mathrm{C}$ following betaine addition to the diet, whereas in the present study pigs of a similar age and $\mathrm{BW}$ were kept at approximately $20^{\circ} \mathrm{C}$.

There were no effects $(\mathrm{P}>0.05)$ of betaine supplementation alone or combined with organic acids and/or inulin on the level of microbial metabolites, including SCFA, D- and L-lactic acid, DAP and ornithine, both at the ileal and faecal levels (Tables 7 and 8). D-lactic acid was not analysed in faeces due to relatively small concentrations compared to those in ileal digesta. These findings are in agreement with the observation that there were also no treatment effects on ileal and total tract digestibilities of NDF and ADF, indicating that supplementary betaine, organic acids and inulin, supplied alone or in combination, did not stimulate the fermentation of these dietary fibre fractions. In contrast, recent studies in piglets revealed higher ileal and/or total tract fibre digestibilities due to microbial fermentation of dietary fibre following the supplementation of betaine (Eklund et al., 2006a,b; Ratriyanto et al., 2007) or inulin (Böhmer et al., 2005).

The supplementation of betaine alone or combined with organic acids and/ or inulin did not affect ileal or total tract digestibilities of $\mathrm{CP}$ and AA, which 
is in contrast with studies in which betaine had a positive impact both on ileal and total tract digestibilities (Eklund et al., 2006a,b; Ratriyanto et al., 2007). Higher ileal CP and AA digestibilities following betaine supplementation have been attributed to improvements in enzymatic digestion conditions and higher

Table 7. Concentrations of microbial metabolites in ileal digesta of pigs fed on diets supplemented with betaine, organic acids, inulin and their combinations

\begin{tabular}{|c|c|c|c|c|c|c|c|c|c|}
\hline \multirow[b]{2}{*}{ Item $^{2}$} & \multicolumn{8}{|c|}{ Treatments $^{1}$} & \multirow[b]{2}{*}{$\begin{array}{c}\text { Pooled } \\
\text { SEM }\end{array}$} \\
\hline & $\mathrm{CON}$ & BET & $\mathrm{AC}$ & IN & $\begin{array}{l}\text { BET } \\
+\mathrm{AC} \\
\end{array}$ & $\begin{array}{l}\text { BET } \\
+ \text { IN } \\
\end{array}$ & $\begin{array}{l}\mathrm{AC} \\
+\mathrm{IN} \\
\end{array}$ & $\begin{array}{c}\text { BET+ } \\
\mathrm{AC}+\mathrm{IN}\end{array}$ & \\
\hline \multicolumn{10}{|l|}{$\overline{g / k g ~ D M}$} \\
\hline D-lactic acid & 2.5 & 6.0 & 5.0 & 2.8 & 5.8 & 2.7 & 6.6 & 2.1 & 2.45 \\
\hline L-lactic acid & 8.8 & 14.7 & 14.1 & 9.8 & 14.7 & 10.3 & 15.8 & 10.5 & 2.79 \\
\hline total lactic acid & 11.3 & 20.6 & 19.1 & 12.6 & 20.5 & 13.0 & 22.4 & 12.5 & 5.16 \\
\hline \multicolumn{10}{|l|}{$m g / k g D M$} \\
\hline DAP & 50.5 & 45.3 & 42.6 & 50.5 & 47.1 & 61.1 & 46.9 & 48.1 & 8.56 \\
\hline ornithine & 186.8 & 209.1 & 188.2 & 170.3 & 172.9 & 189.9 & 204.4 & 154.2 & 29.59 \\
\hline \multicolumn{10}{|l|}{$\mathrm{mmol} / \mathrm{kg} \mathrm{DM}$} \\
\hline acetic acid & 144.2 & 144.4 & 171.2 & 162.7 & 121.2 & 182.0 & 156.3 & 186.5 & 21.49 \\
\hline propionic acid & 23.5 & 28.6 & 24.9 & 24.0 & 21.7 & 31.8 & 27.5 & 25.2 & 5.14 \\
\hline butyric acid & 6.4 & 6.8 & 10.5 & 7.6 & 6.4 & 8.7 & 11.3 & 8.3 & 2.88 \\
\hline isovaleric acid & 0.4 & 0.3 & 1.0 & 0.6 & 0.5 & 0.8 & 0.8 & 1.0 & 0.32 \\
\hline valeric acid & 0.5 & 0.3 & 1.1 & 0.6 & 0.3 & 0.9 & 1.6 & 0.0 & 0.47 \\
\hline total SCFA & 178.1 & 179.3 & 208.3 & 196.7 & 149.0 & 226.8 & 200.1 & 216.6 & 27.66 \\
\hline
\end{tabular}

Table 8. Concentrations of microbial metabolites in faeces of pigs fed on diets supplemented with betaine, organic acids, inulin and their combinations

\begin{tabular}{|c|c|c|c|c|c|c|c|c|c|}
\hline \multirow[b]{2}{*}{ Item } & \multicolumn{8}{|c|}{ Treatments $^{1}$} & \multirow[b]{2}{*}{$\begin{array}{c}\text { Pooled } \\
\text { SEM }\end{array}$} \\
\hline & $\mathrm{CON}$ & BET & $\mathrm{AC}$ & IN & $\begin{array}{l}\text { BET } \\
+ \text { AC }\end{array}$ & $\begin{array}{l}\text { BET } \\
+ \text { IN }\end{array}$ & $\begin{array}{l}\mathrm{AC} \\
+\mathrm{IN}\end{array}$ & $\begin{array}{c}\text { BET+ } \\
\text { AC+IN }\end{array}$ & \\
\hline L-lactic acid, g/kg DM & 0.2 & 0.4 & 0.2 & 0.4 & 0.4 & 0.3 & 0.4 & 0.4 & 0.09 \\
\hline \multicolumn{10}{|l|}{$m g / k g D M$} \\
\hline DAP & 584.4 & 652.4 & 719.8 & 648.4 & 645.3 & 750.2 & 802.1 & 599.4 & 69.70 \\
\hline ornithine & 128.1 & 183.8 & 187.1 & 173.5 & 207.3 & 195.7 & 248.6 & 163.5 & 33.75 \\
\hline \multicolumn{10}{|l|}{$\mathrm{mmol} / \mathrm{kg} \mathrm{DM}$} \\
\hline acetic acid & 227.5 & 271.0 & 329.2 & 286.5 & 271.1 & 272.8 & 308.5 & 242.9 & 29.46 \\
\hline propionic acid & 74.6 & 109.9 & 111.0 & 96.3 & 97.2 & 79.2 & 95.9 & 68.0 & 11.84 \\
\hline isobutyric acid & 11.7 & 10.6 & 14.2 & 13.8 & 13.0 & 12.4 & 13.2 & 9.7 & 1.35 \\
\hline butyric acid & 32.2 & 45.7 & 45.7 & 37.5 & 43.8 & 40.0 & 43.4 & 27.1 & 8.17 \\
\hline isovaleric acid & 18.3 & 16.7 & 22.6 & 21.5 & 20.9 & 19.5 & 20.7 & 15.5 & 2.43 \\
\hline valeric acid & 12.9 & 15.7 & 15.2 & 14.1 & 14.7 & 14.0 & 14.7 & 10.8 & 2.87 \\
\hline total SCFA & 375.0 & 462.6 & 541.6 & 467.4 & 463.3 & 436.9 & 490.4 & 376.2 & 52.56 \\
\hline
\end{tabular}

${ }^{1}$ explanation see Table 3 
absorption capacity of the intestinal epithelium (Eklund et al., 2006b). On the other hand, disappearance of AA in the large intestine, resulting in higher total tract $\mathrm{CP}$ and $\mathrm{AA}$ digestibilities, has been associated with enhanced microbial fermentation of AA (Mosenthin and Rademacher, 2003) that are used as an energy source by the intestinal microbiota (Mosenthin et al., 1992). The lack of possible betaine effects on protein fermentation and disappearance of AA in the large intestine may be attributed to the fact that the $\mathrm{CP}$ content in the present study was relatively low (155 g/kg, as fed), whereas the corresponding value in the aforementioned study by Eklund et al. (2006b) was $210 \mathrm{~g} / \mathrm{kg}$ diet (as fed).

A blend of organic acids supplemented alone or in combination with betaine to piglet's diet did not affect $(\mathrm{P}>0.05)$ nutrient digestibilities or the concentration of various microbial metabolites both at the ileal and faecal level. Similarly, other authors failed to show any effects of dietary supplementation with organic acids on nutrient digestibility or microbial metabolite concentrations in the small intestine and colon of pigs (e.g., Øverland et al., 2008). Variable responses to dietary supplementation with organic acids depend on several factors, such as the level of inclusion or dietary buffering capacity (Gabert and Sauer, 1994). The buffering capacity of the basal diet used in the present study has not been determined, however, the CP in the basal diet amounted to $155 \mathrm{~g} / \mathrm{kg}$ (as fed). In comparison, when pigs received a basal diet with higher levels of CP $(211 \mathrm{~g} / \mathrm{kg}$, as fed) supplementation with formic acid resulted in higher nutrient digestibilities (Blank et al., 1999). Thus, the potential of organic acids may have been limited in the present study, as the effects of organic acids were more pronounced in diets with a higher CP content, resulting in higher buffering capacity (Blank et al., 1999).

Dietary supplementation with inulin alone or in combination with betaine to a piglet's diet did not affect $(\mathrm{P}>0.05)$ nutrient digestibilities or the concentration of various microbial metabolites both at the ileal and faecal level. In agreement with the results of the present study, other authors failed to show any beneficial effects of dietary inulin supplementation on nutrient digestibilities and the formation of microbial metabolites as well (e.g., Eberhard et al., 2007). Legume seeds and cereals, such as soyabean meal, lupine, wheat and barley, commonly used in feed formulation, already contain substantial amounts of NDO. Therefore, the potential effects of inulin on the variables that were measured may have been masked due to the presence of native NDO in the basal diet originating from soyabean meal, wheat and barley (Houdijk et al., 2002). 


\section{CONCLUSIONS}

The supplementation of betaine, organic acids and inulin did not affect the microbial fermentation of nutrients in the small and large intestine, and subsequently did not affect the microbial metabolite concentrations in ileal digesta and faeces. Combining betaine with organic acids and/or inulin did not show any associated effects on the variables measured.

\section{ACKNOWLEDGEMENTS}

We are grateful to Helga Brehm and Martin Steffl for their excellent work with animal surgery. The receipt of a scholarship from the German Academic Exchange Service, Germany for Adi Ratriyanto is gratefully acknowledged.

\section{REFERENCES}

Blank R., Mosenthin R., Sauer W.C., Huang S., 1999. Effect of fumaric acid and dietary buffering capacity on ileal and fecal amino acid digestibilities in early-weaned pigs. J. Anim. Sci. 77, 2974-2984

Böhmer B.M., Branner G.R., Roth-Maier D.A., 2005. Precaecal and faecal digestibility of inulin (DP 10-12) or an inulin/Enterococcus faecium mix and effects on nutrient digestibility and microbial gut flora. J. Anim. Physiol. Anim. Nutr. 89, 388-396

Brandt M., Allam S.M., 1987. Analytik von $\mathrm{TiO}_{2}$ im Darminhalt und Kot nach Kjeldahlaufschluß. Arch. Anim. Nutr. 37, 453-454

Eberhard M., Hennig U., Kuhla S., Brunner R.M., Kleessen B., Metges C.C., 2007. Effect of inulin supplementation on selected gastric, duodenal, and caecal microbiota and short chain fatty acid pattern in growing piglets. Arch. Anim. Nutr. 61, 235-246

Eklund M., Bauer E., Wamatu J., Mosenthin R., 2005. Potential nutritional and physiological functions of betaine in livestock. Nutr. Res. Rev. 18, 31-48

Eklund M., Mosenthin R., Piepho H.P., 2006b. Effects of betaine and condensed molasses solubles on ileal and total tract nutrient digestibilities in piglets. Acta Agr. Scand., Sect. A, Anim. Sci. $56,83-90$

Eklund M., Mosenthin R., Tafaj M., Wamatu J., 2006a. Effects of betaine and condensed molasses solubles on nitrogen balance and nutrient digestibility in piglets fed diets deficient in methionine and low in compatible osmolytes. Arch. Anim. Nutr. 60, 289-300

Fang R.J., Li T.J., Yin F.G., Yin Y.L., Kong X.F., Wang K.N., Yuan Z., Wu G.Y., He J.H., Deng Z.H., Fan M.Z., 2007. The additivity of true or apparent phosphorus digestibility values in some feed ingredients for growing pigs. Asian-Austr. J. Anim. Sci. 20, 1092-1099

Farooqi H.A.G., Khan M.S., Khan M.A., Rabbani M., Pervez K., Khan J.A., 2005. Evaluation of betaine and vitamin $\mathrm{C}$ in alleviation of heat stress in broilers. Int. J. Agr. Biol. 5, 744-746

Gabert V.M., Sauer W.C., 1994. The effects of supplementing diets for weanling pigs with organic acids. A review. J. Anim. Feed Sci. 3, 73-83 
Houdijk J.G.M., 1998. Effects of non-digestible oligosaccharides in young pig diets. $\mathrm{PhD}$. Thesis, Wageningen University (The Netherlands)

Houdijk J.G.M., Hartemink R., Verstegen M.G.A., Bosch M.W., 2002. Effects of dietary nondigestible oligosaccharides on microbial characteristics of ileal chyme and faeces in weaner pigs. Arch. Anim. Nutr. 56, 297-307

Klasing K.C., Adler K.L., Remus J.C., Calvert C.C., 2002. Dietary betaine increases intraepithelial lymphocytes in the duodenum of coccidia-infected chicks and increases functional properties of phagocytes. J. Nutr. 132, 2274-2282

Li S., Sauer W.C., Fan M.Z., 1993. The effect of dietary crude protein level on amino acid digestibility in early-weaned pigs. J. Anim. Physiol. Anim. Nutr. 70, 26-37

LorzA., Metzger E., 1999. Tierschutzgesetz: Tierschutzgesetz mit allgemeiner Verwaltungsvorschrift, Rechtsverordnungen und europaeischen Übereinkommen; Kommentar. $5^{\text {th }}$ Edition. Beck, Munich (Germany)

Mongin P., 1976. Ionic constituents and osmolality of the small intestineal fluids of the laying hen. Brit. Poultry Sci. 17, 383-392

Mosenthin R., Rademacher M., 2003. Digestible amino acids in diet formulation for pigs. In: J.P.F. D’Mello (Editor). Amino Acids in Animal Nutrition. CABI Publishing. Wallingford, Oxon (UK), pp. 169-196

Mosenthin R., Sauer W.C., Ahrens F., De Lange C.F.M., Bornholdt U., 1992. Effect of dietary supplements of propionic acid, siliceous earth or a combination of these on the energy, protein and amino acid digestibilities and concentrations of microbial metabolites in the digestive tract of growing pigs. Anim. Feed Sci. Tech. 37, 245-255

Naumann C., Bassler R., 1997. Die chemische Untersuchung von Futtermitteln. In: C. Naumann, R. Bassler (Editors). Handbuch der landwirtschaftlichen Versuchs- und Untersuchungsmethodik. VDLUFA-Verlag, Darmstadt (Germany)

NRC, 1998. Nutrient Requirement of Swine. 10 $0^{\text {th }}$ Edition. National Research Council. National Academic Press. Washington, DC

Øverland M., Kjos N.P., Borg M., Skjerve E., Sørum H., 2008. Organic acids in diets for entire male pigs: Effect on skatole level, microbiota in digesta, and growth performance. Livest. Sci. 115, 169-178

Piepho H.P., 2004. An algorithm for a letter-based representation of all-pairwise comparisons. J. Comput. Graph. Stat. 13, 456-466

Ratriyanto A., Mosenthin R., Eklund M., 2007. Effect of graded levels of dietary betaine on ileal and total tract digestibilities and intestinal microbial fermentation in piglets. Proceedings of $119^{\text {th }}$ VDLUFA Congress, Göttingen. VDLUFA-Verlag, Darmstadt (Germany), p. 87

SAS, 2003. SAS User's Guide: Statistics, Version 9. SAS Institute Inc. Cary, NC

Spreeuwenberg M.A.M.S., Van Hees H.M.J., Smits C.H.M., 2007. The effect of betaine supplementation on growth performance of piglets raised under sub-optimal management conditions. In: J.E. Paterson, J.A. Barker (Editors). Manipulating Pig Production XI. Australasian Pig Science Association. Scott Print, Perth, Western Australia, p. 186

Steer T., Carpenter H., Tuohy K., Gibson G.R., 2000. Perspectives on the role of the human gut microbiota and its modulation by pro- and prebiotics. Nutr. Res. Rev. 13, 229-254

Zijlstra J.B., Beukema J., Wolthers B.G., Byrne B.M., Groen A., Dankert J., 1977. Pretreatment methods prior to gaschromatographic analysis for volatile fatty acids from faecal samples. Clin. Chim. Acta 78, 243-250 